\title{
表情を利用した心理評価の基礎的研究 \\ Fundamental Study for Evaluating Emotion from Facial Expression
}

\author{
○阿部武志，秋山庸子， 泉佳伸，西嶋茂宏 \\ 大阪大学大学院工学研究科
}

- Takeshi Abe, Yoko Akiyama, Yoshinobu Izumi, Shigehiro Nishijima

Graduate school of engineering, Osaka University

\section{1. 躇吾}

介護福祉や心理療法の現場において、コミュニケーションは重 要な役割を果たしている。特に発語が困難な高齢者や障害者に は非言語的なコミュニケーションの手段が必要になると考えられる。 非言語的な手法の中でも表情は、介護者や要介護者共に負担 がかかることも無く、含まれる情報量が多いため、有効な手段の 一つだと考えられる。本研究では、表情を用いて、客観的かつ簡 易に測定でき、解析できる手法の確立を試みた。

\section{2. 解析}

基本となる感情表情として、怒り、嫌覀、恐怖、幸福、悲 しみ、驚きを選択した。この6つの感情(基本 6 感情)は Ekman らの研究[1]により、人種や文化、性別に関係なく共通に持っ ているとされる感情である。さらに他の感情についても、こ の 6 感情の組み合わせで表すことができるといわれている。 本研究では式(2.1)を用いて、現在の表情を基本 6 感情によっ て表すことを試みた。式(2.1)では、A が現在の表情を、B が 基本 6 表情を表している。

各表情の無表情に対する表情変化を $\left[\begin{array}{llll}\mathrm{x}_{01} & \mathrm{x}_{02} & \ldots & \mathrm{x}_{14}\end{array}\right]^{\mathrm{T}}\left[\begin{array}{l}\mathrm{F} 01 \\ \mathrm{n}\end{array}\right.$ F02 ...F F14]の形で表した。ここでFは、"左上臉を上げる”や” 上唇を上げる”など、全 14 個の表情変化を表している。また $\mathrm{x}_{\mathrm{i}}$ は式(2.2)で表すように 3 值化した。

$$
x_{i}=\left\{\begin{array}{cl}
1 & (F i \text { 示された変化をしている) } \\
0 & (\text { 変化していない }) \\
-1 & \text { (逆向きに変化している) }
\end{array}\right.
$$

この手法により、無表情に対する基本 6 表情の変化を 6 列 にまとめたものが式(2.1)のB となった。a,b, c, d, e, f はそれぞ れ怒り、嫌悪、恐怖、幸福、悲しみ、驚きを意味している。 式(2.1)の B にある、(6,14)型の行列式を基本 6 表情マトリクス と名づけた。

y は基本 6 表情がそれぞれ、現在の表情にどれ程関与して いるかを意味し、ここではこれを表情の寄与率と定義する。

よって式(2.1)によって測定で得た現在の表情に対する基本 6 表情それぞれの寄与率を求めることができる。本研究では、 $\mathrm{y}$ を基本 6 表情の寄与率であると同時に、基本 6 感情の寄与 率として仮定した。よって、被験者の現在の感情を基本 6 感 情の奇与率で推定することが可能となる。

\section{3. 英験}

まずEkman \& Friesen の著書”表情分析入門”に例示されてい

$$
\left(\begin{array}{llll}
\mathrm{x}_{01} & \mathrm{x}_{02} & \cdots & \mathrm{x}_{16}
\end{array}\right)\left(\begin{array}{c}
\mathrm{F} 01 \\
\mathrm{~F} 02 \\
\vdots \\
\mathrm{F} 16
\end{array}\right]=\left[\begin{array}{llll}
\mathrm{y}_{\mathrm{a}} \mathrm{y}_{\mathrm{b}} \mathrm{y}_{\mathrm{c}} \mathrm{y}_{\mathrm{d}} \mathrm{y}_{\mathrm{e}} \mathrm{y}_{\mathrm{f}}
\end{array}\right]\left(\begin{array}{cccc}
\mathrm{X}_{\mathrm{a}, 01} & \mathrm{X}_{\mathrm{a}, 02} & \cdots & \mathrm{X}_{\mathrm{a}, 16} \\
\mathrm{X}_{\mathrm{b}, 01} & \mathrm{X}_{\mathrm{b}, 02} & \cdots & \mathrm{X}_{\mathrm{b}, 16} \\
\mathrm{X}_{\mathrm{c}, 01} & \mathrm{X}_{\mathrm{c}, 02} & \cdots & \mathrm{X}_{\mathrm{c}, 16} \\
\mathrm{X}_{\mathrm{d}, 01} & \mathrm{X}_{\mathrm{d}, 02} & \cdots & \mathrm{X}_{\mathrm{d}, 16} \\
\mathrm{X}_{\mathrm{e}, 01} & \mathrm{X}_{\mathrm{e}, 02} & \cdots & \mathrm{X}_{\mathrm{e}, 16} \\
\mathrm{X}_{\mathrm{f}, 01} & \mathrm{X}_{\mathrm{f}, 02} & \cdots & \mathrm{X}_{\mathrm{f}, 16}
\end{array}\right]\left[\begin{array}{c}
\mathrm{F} 01 \\
\mathrm{~F} 02 \\
\vdots \\
\mathrm{F} 16
\end{array}\right]
$$

る基本 6 表情の表情画像を用いて、式(2.1)の B のような基本 6 表情マトリクスを、無表情の画像を基準として作成した。次に嫌悪 と驚きの表情の合成写真を現在の表情と仮定して式(2.1)の A を 得た。これらを用いて寄与率を求め、合成に使われた 2 つの基本 表情が㟢与しているかどうかを確認した。

\section{4. 結果と考察}

嫌覀と驚きの合成表情写真で得られた寄与率をFig. 1 に示す。 嫌悪の表情の寄与率は $\mathrm{y}_{\mathrm{b}}=0.5$ 、驚きの表情の寄与率は $\mathrm{y}_{\mathrm{f}}=0.6$ と 表され、2 つの基本表情を検出することができた。このことにより、 本手法の妥当性が示された。

以上のことから、全 14 個の顔のパーツの変化といら簡易な判定 から、心理評価を客観的に行うことができる可能性が示された。

今後は、基本 6 表情マトリクスに個人差があるかどうかを検討し、 この解析方法を普遍化して使用できることを目指寸。

\section{5. 参考文献}

1）Pエクマン/W.V.フリーセン. 表情分析入門. 第 8 刷. 誠信書 房, 2003.

\begin{tabular}{|c|c|}
\hline コード & 注目した特徴点 \\
\hline $\mathrm{F} 01, \mathrm{~F} 03$ & 眉外側Y軸方向 (左，右) \\
\hline $\mathrm{F} 02, \mathrm{~F} 04$ & 眉内側Y軸方向 (左，右) \\
\hline F05, F07 & 上眼瞼Y軸方向 (左，右) \\
\hline F06, F08 & 下目瞼Y軸方向 (左，右) \\
\hline F09, F11 & 口角X軸方向 (左，右) \\
\hline$F 10, F 12$ & 口角Y軸方向 (左，右) \\
\hline F13 & 上唇Y軸方向 \\
\hline F14 & 下票Y軸方向 \\
\hline
\end{tabular}

Table 1 注目した変化とそのコード (i)

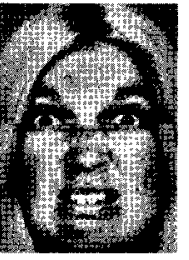

(ii)

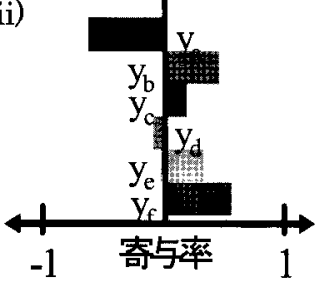

a:怒り

b: 嫌悪

$\mathrm{c}$ :恐怖

d: 幸福

e:悲しみ
Fig. 1 (i)実験に使用した合成表情写真 (ii)合成表情写真加得られた寄与率 